\title{
INTERMITTENT BIRDING AT PRINCE ALBERT, 1982-1985
}

DAVID H. WRIGHT, \#1601 - 415 Heritage Crescent, Saskatoon, SK. S7H 5N3

Over 13 years I have recorded 95 species of birds in the Prince Albert area, some during short walks of 30 to 90 minutes near the Court House, some in the Little Red River Park along the north shore of the river, and some in the Spruce River wetlands $10 \mathrm{~km}$ north of the city along Highway 2. The most interesting observations were made at the latter marsh, especially where a concrete bridge spans the river on the service road paralleling the east side of the highway. Young of the Canada Goose, American Wigeon and American Coot were observed in the marsh, and a pair of territorial Northern Harriers dive-bombed me on 1 June 1994; they must have had a marsh nest nearby. The McCown's Longspur is an addition to the local list.

Observations of nine species were of special interest to me, they are as follows:

Merlin. An adult Merlin took a Redwinged Blackbird in the marsh just west of Highway 2 on 15 July 1991; later this bird perched on a telephone pole and plucked the kill.

American Avocet. On 22 May 1990 and again six days later, on the eastern side of the marsh, I located two nests on a mud flat. One had three eggs and the other, four. The incubating adults could be seen quite clearly from the service road and did not seem to be particularly concerned by the traffic. This a northernmost nest record for this longitude.
Common Snipe. Just northwest of the concrete bridge, I regularly heard on a summer evening, the eerie whinny made by air passing through the bird's feathers as it dives. A truly wonderful sound!

Cliff Swallow. Nests were present beneath the concrete bridge, on 22 May 1990 and 15 July 1992.

Marsh Wren. I have only one sighting, made at the marsh.

Red-winged Blackbird. On 16 June 1982 , I made a thorough check of all the nests I could locate on either side of the service road. Three nests contained four eggs, one contained one egg, and another seven as yet had none. I was surprised by the variation in the number of eggs and in the total lack of any eggs of the Brown-headed Cowbird. Yellowheaded Blackbirds also had nests in this marsh.

McCown's Longspur. On 27 September 1983, in the shrubs near the federal court house, I spotted a small flock of four to five adults. This was a surprise. I was able to see the head markings, white throat and black triangle on the upper breast of the male. I presume they had wandered north of their breeding range before beginning their fall migration. This is a species not previously recorded in the area.

Pine Siskin. I had winter records at Red River Park, including 9 February 1990, 4 and 21 March 1989, and 14 March 1994. 